\title{
Н.А. Гринчак
}

Національна академія статистики, обліку та аудиту, Україна

\section{ЗАСТОСУВАННЯ МЕТОДУ ГОЛОВНИХ КОМПОНЕНТ ДЛЯ ВИЗНАЧЕННЯ ФАКТОРІВ РОЗВИТКУ РИНКУ ЛОГІСТИЧНИХ ПОСЛУГ УКРАЇНИ}

Виокремлені та обтрунтовані основні фактори впливу на розвиток ринку логістичних послуг України на основі проведення факторного аналізу методом головних компонент. Виявлено три фактори, щьо пояснюють 83,1 \% сумарної варіації досліджуваних ознак, а саме: динаміка цін на транспортні послуги; обсяг міжнародної торгівлі Украйни товарами; оптовий та роздрібний внутрішній товарооборот Украӥни.

Ключові слова: вантажні перевезення, метод головних компонент, ринок логістичних послуг, складське господарство, статистичне оцінювання, факторний аналіз.

\section{Постановка проблеми}

Останні роки всі зусилля провайдерів логістичних послуг були направлені на подолання нових перешкод викликаних політичними і економічними чинниками. Висока вартість запозичених коштів та падіння курсу національної валюти відразу збільшили «важіль» логістичних рішень, суттєво зріс вплив оборотності товарних запасів і логістичних затримок на фінансовий результат бізнесу. Подальший розвиток ринку логістичних послуг нерозривно пов'язаний з розвитком економіки, внутрішньої та зовнішньої торгівлі, умовами для залучення інвестицій, обсягом і прозорістю державного регулювання. Ситуація з безпечністю перевезень загострена до межі. На тлі вищезазначених умов, виокремлюється низка чинників, які можуть прямо чи опосередковано впливати на розвиток ринку логістичних послуг. Визначення стримуючих чи стимулюючих чинників розвитку ринку логістичних послуг, які $є$ важливою передумовою для розробки нової політики чи стратегії розвитку ринку логістичних послуг України у середньо- та довгостроковій перспективі.

\section{Аналіз останніх досліджень і публікацій}

Дослідженню факторів, які впливають на розвиток ринку логістичних послуг присвятили увагу в своїх працях такі українські та зарубіжні вчені, як Григорак М. Ю. [1], Інцзе Джу (Yingjie Ju) [2], Лаззат Габдулліна (Lazzat Gabdullina) [3], Пойта I. O. [4], Супачарт Ямратанакул (Supachart Iamratanakul) [5], Фам Ван Хонга (Pham Van Honga), Танх-Туй Нгуєнб (Thanh Thuy Nguyenb) [6], Чі-Ю Лін (Chieh-Yu Lin) [7], Шандрівська О. Є. [8].

Метою цієї статті $\epsilon$ виявлення, визначення сили впливу та ранжування за рівнем значущості основних факторів впливу на розвиток ринку логістичних послуг України.

\section{Виклад основного матеріалу}

Для отримання прогнозів розвитку національних чи міжнародних ринків використовуються кількісні методи прогнозування, зокрема, метод часових рядів, кореляційний та регресійний аналіз, метод імітаційного моделювання, економетричні моделі тощо. Зазначені методи грунтуються на екстраполюванні минулого, що обмежує можливості ïх застосування для прогнозування впливу факторів розвитку економіки, зокрема зовнішньої та внутрішньої торгівлі на розвиток ринку логістичних послуг, оскільки цей розвиток залежить від багатьох соціально-економічних, екологічних, політичних, фінансових та інших складних процесів та явищ, які складно описати кількісно.

Для визначення впливу різних економічних факторів на розвиток ринку логістичних послуг скористаємося методом головних компонент та кореляційно-регресійним аналізом. При моделюванні складних причинних комплексів, таких як ринок логістичних послуг, як правило стикаються 3 проблемою надлишковості інформації, коли екзогенні змінні які, включені в ознаковий простір моделі, висококорельовані (мультиколінеарні). Щоб забезпечити адекватність моделі впливу різних чинників на розвиток ринку логістичних послуг в реальному процесі, вдамося до заміни такого типу ознакової множини меншою кількістю некорельованих величин, які б зберігали всю інформацію щодо причинно-наслідкового механізму формування ринку і не впливали на точність результатів аналізу. Інструментом такої заміни $є$ факторний аналіз [9]. Саме факторний аналіз дозволяє виявити вплив прихованих (латентних) факторів на загальний результат, та виразити їх кількісно. Для 
визначення впливу різних чинників розвитку економіки країни на розвиток ринку логістичних послуг скористуємося факторним та кореляційнорегресійним аналізом.

Застосування методу факторного аналізу до оцінки розвитку ринку логістичних послуг грунтується на припущені, що показники різних блоків $\epsilon$ лише індикаторами певних існуючих характеристик ринку, які безпосередньо не вимірюються. Першопричина кореляції показників кожного блоку, як відомо, називається компонентною. В кожному блоці, що характеризує певний аспект розвитку ринку логістичних послуг, виділяється декілька компонент. Показники, що належать до різних компонент некорельовані, отже, і компоненти $\epsilon$ незалежними. Ідентифікація компонент залежить від показників, які мають найбільші факторні навантаження.

Якщо кількість факторів перевищує одиницю, зазвичай здійснюють обертання матриці факторного відображення для одержання більш простої іiі структури.

Для виявлення впливу низки емпіричних даних, що є доступними у офіційній статистичній звітності [10], до аналізу були включені 9 показників:

$\mathrm{X}_{1}$ - оптовий товарооборот підприємств, млн грн;

$\mathrm{X}_{2}$ - оборот роздрібної торгівлі, млн грн;

$\mathrm{X}_{3}$ - обсяг експорту товарів, млн дол. США;

$\mathrm{X}_{4}$ - обсяг імпорту товарів, млн дол. США;

$\mathrm{X}_{5}$ - індекс девальвації гривні відносно долару США, \%;

$\mathrm{X}_{6}$ - індекс тарифів на вантажні залізничні перевезення, \%;

$\mathrm{X}_{7}$ - індекс споживчих цін на транспорт, \%;

$\mathrm{X}_{8}$ - індекс споживчих цін на паливо та мастила, \%;

$\mathrm{X}_{9}$ - індекс споживчих цін на транспортні послуги, \%.
Модель побудовано 3 використанням прикладного пакету "Statistica" версії 6.0, зокрема модуля "Factor analysis" методу "Principal components".

В результаті процедур, проведених за комп'ютерною програмою, одержано наступні результати.

Для візуалізації оцінки виокремлення головних компонент скористаємося графічним критерієм “кам'янистого обвалу” (рис. 1). Значення властивих чисел кореляційної матриці представлено на осі ординат. Як бачимо ці значення стрімко зменшуються, і не можна чітко виділити кількість факторів: 3 або ж 4.

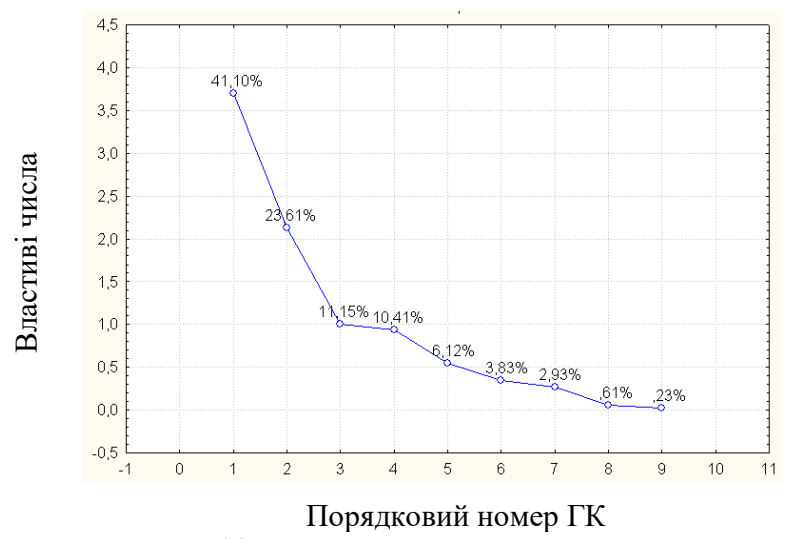

Рис. 1. Графічне в1доораження розрахованих властивих чисел

В таблиці 1. відображені значення властивих чисел, які $є$ дисперсіями головних компонент, а також внесок кожної 3 них у сумарну варіацію ознакової множини.

3 рис. 1 та табл. 1 видно, що виділення 3 факторів дозволить описати $75,86 \%$ загальної дисперсії, а виділення 4 факторів дозволить описати 86,3 \% загальної дисперсії, що є цілком прийнятним для нашого випадку (кожен фактор вносить вклад більше $10 \%$ в загальну дисперсію), властиві значення більше 1.

Таблиця 1

Таблиця властивих значень матриці кореляції

\begin{tabular}{|c|c|c|c|c|}
\hline № значення & $\begin{array}{c}\text { Властиві } \\
\text { значення }\end{array}$ & $\begin{array}{c}\text { Частки загальної } \\
\text { дисперсї, \% }\end{array}$ & $\begin{array}{c}\text { Накопичені } \\
\text { властиві значення }\end{array}$ & $\begin{array}{c}\text { Накопичені частки } \\
\text { загальної дисперсії, \% }\end{array}$ \\
\hline Фактор 1 & 3,699426 & 41,10474 & 3,699426 & 41,1047 \\
\hline Фактор 2 & 2,124633 & 23,60703 & 5,824059 & 64,7118 \\
\hline Фактор 3 & 1,003567 & 11,15074 & 6,827626 & 75,8625 \\
\hline Фактор 4 & 0,937129 & 10,41254 & 7,764755 & 86,2751 \\
\hline Фактор 5 & 0,550602 & 6,12002 & 8,315557 & 92,3951 \\
\hline Фактор 6 & 0,344391 & 3,82657 & 8,659948 & 99,2216 \\
\hline Фактор 7 & 0,264100 & 2,93445 & 8,924049 & 99,7702 \\
\hline Фактор 8 & 0,055266 & 0,61406 & 8,979314 & 100,0000 \\
\hline Фактор 9 & 0,020686 & 0,22984 & 9,000000 & \\
\hline
\end{tabular}


У 4-го фактора властиве значення менше 1 але воно доволі близько до одиниці. Спробуємо виділити 3 та 4 фактори і подивитися на результат.

Внесок першого фактору (компоненти) в сумарну дисперсію ознакової множини становить $41,1 \%$, другого - 23,6 \%, третього - $11,2 \%$, четвертого - 10,4\%. Разом (Cumul.\%) чотири фактори (компоненти) пояснюють 86,3\% сумарної варіації, що свідчить про високий ступінь факторизації.

Аналізуючи рис. 1 та табл. 1 майже не можливо прийти до якогось задовільного висновку, бо результати важко піддаються інтерпретації, а також постає питання про логічний зміст чотирьох утворених факторів. Враховуючи це, для одержання простої факторної структури показників впливу на ринок логістичних послуг було використано метод ортогонального обертання varimax, застосування якого дало можливість перейти від 9 змінних до 4 факторів, що є некорельованими між собою і разом описують 86,3 \% загальної дисперсії початкових даних блоку.

Факторні навантаження показників наведено у таблиці 2.

Таблиця 2

Розраховані значення факторних навантажень після обертання (варімакс нормалізований)

\begin{tabular}{|c|c|c|c|c|}
\hline Ознаки & Фактор 1 & Фактор 2 & Фактор 3 & Фактор 4 \\
\hline $\mathrm{X}_{1}$ & $-0,157280$ & 0,062678 & $\mathbf{- 0 , 9 0 2 7 7 0}$ & $-0,158211$ \\
\hline $\mathrm{X}_{2}$ & $-0,078732$ & 0,242711 & $-0,234846$ & $\mathbf{- 0 , 8 6 7 4 7 9}$ \\
\hline $\mathrm{X}_{3}$ & $-0,029783$ & $\mathbf{- 0 , 9 6 7 5 6 2}$ & 0,117669 & 0,111662 \\
\hline $\mathrm{X}_{4}$ & $-0,097323$ & $\mathbf{- 0 , 9 7 5 8 5 3}$ & $-0,077317$ & 0,020161 \\
\hline $\mathrm{X}_{5}$ & 0,599365 & 0,094864 & 0,591413 & $-0,028643$ \\
\hline $\mathrm{X}_{6}$ & $\mathbf{0 , 8 1 3 9 3 5}$ & 0,062142 & $-0,004448$ & $-0,160460$ \\
\hline $\mathrm{X}_{7}$ & $\mathbf{0 , 9 2 2 8 9 7}$ & 0,080551 & 0,208690 & 0,237443 \\
\hline $\mathrm{X}_{8}$ & $\mathbf{0 , 8 8 6 0 6 0}$ & 0,002411 & 0,236855 & 0,142406 \\
\hline $\mathrm{X}_{9}$ & 0,634977 & 0,209100 & $-0,171278$ & 0,620414 \\
\hline Властиві значення & 3,103060 & 2,014381 & 1,368748 & 1,278566 \\
\hline Внесок компонент, \% & 0,344784 & 0,223820 & 0,152083 & 0,142063 \\
\hline
\end{tabular}

На основі визначених факторних навантажень (табл. 2), можна визначити, що показники чинники $\mathrm{X}_{5}$ - індекс девальвації гривні відносно долару США та $\mathrm{X}_{9}$ - індекс споживчих цін на транспортні послуги не мають суттєвого впливу на розвиток ринку логістичних послуг. Це пояснюється тим, що індекс споживчих цін на транспортні послуги більше впливатиме на пасажирські перевезення, ані ж на транспортні, а пасажирські перевезення були виключені зі статистичного дослідження ринку логістичних послуг. Девальвація гривні не впливає на ефективність зовнішньої торгівлі, і як результат на ринок логістичних послуг, який пов'язаний 3 міжнародними перевезеннями.

Такі проміжні результати дозволили вилучити чинники $\mathrm{X}_{5}$ - індекс девальвації гривні відносно долару США та $\mathrm{X}_{9}$ - індекс споживчих цін на транспортні послуги 3 запропонованого раніше переліку та використовуючи метод ортогонального обертання varimax перейти від 7 змінних до 3 факторів, що є некорельованими між собою і разом описують 83,1% загальної дисперсії початкових даних блоку (табл. 3).

Таблиця 3

Розраховані значення факторних навантажень після обертання (варімакс нормалізований)

\begin{tabular}{|c|c|c|c|}
\hline Ознаки & Фактор 1 & Фактор 2 & Фактор 3 \\
\hline $\mathrm{X}_{1}$ & $-0,250760$ & 0,008264 & $\mathbf{0 , 7 9 0 5 4 5}$ \\
\hline $\mathrm{X}_{2}$ & $-0,115290$ & $-0,270167$ & $\mathbf{0 , 7 6 1 3 0 5}$ \\
\hline $\mathrm{X}_{3}$ & $-0,015819$ & $\mathbf{0 , 9 6 1 7 8 7}$ & $-0,178854$ \\
\hline $\mathrm{X}_{4}$ & $-0,101632$ & $\mathbf{0 , 9 8 1 0 1 5}$ & 0,026311 \\
\hline $\mathrm{X}_{6}$ & $\mathbf{0 , 8 4 5 6 6 9}$ & $-0,090999$ & 0,122364 \\
\hline $\mathrm{X}_{7}$ & $\mathbf{0 , 9 1 7 9 2 9}$ & $-0,074225$ & $-0,232928$ \\
\hline $\mathrm{X}_{8}$ & $\mathbf{0 , 9 1 8 7 8 7}$ & $-0,017704$ & $-0,221837$ \\
\hline Властиві значення & 2,488672 & 1,974586 & 1,355668 \\
\hline Внесок компонент, \% & 0,355525 & 0,282084 & 0,193667 \\
\hline
\end{tabular}

Внесок першого фактору (компоненти) в сумарну дисперсію ознакової множини становить $39,4 \%$, другого - 30,3\%, третього - 13,4\%. Разом
(Cumul.\%) три фактори (компоненти) пояснюють $83,1 \%$ сумарної варіації ознак, що свідчить про високий ступінь факторизації (табл.4). 
Таблиця властивих значень

\begin{tabular}{|c|c|c|c|c|}
\hline № значення & $\begin{array}{c}\text { Властиві } \\
\text { значення }\end{array}$ & $\begin{array}{c}\text { Частки загальної } \\
\text { дисперсії, \% }\end{array}$ & $\begin{array}{c}\text { Накопичені } \\
\text { властиві }\end{array}$ & $\begin{array}{c}\text { Накопичені частки } \\
\text { загальної дисперсії, \% }\end{array}$ \\
\hline Фактор 1 & 2,760293 & 39,43276 & 2,760293 & 39,43276 \\
\hline Фактор 2 & 2,121143 & 30,30204 & 4,881436 & 69,73480 \\
\hline Фактор 3 & 0,937490 & 13,39272 & 5,818926 & 83,12751 \\
\hline
\end{tabular}

На основі визначених факторних навантажень перший фактор пояснюють такі показники:

$\mathrm{X}_{6}$-індекс тарифів на вантажні залізничні перевезення, \%;

$\mathrm{X}_{7}$ - індекс споживчих цін на транспорт, \%;

$\mathrm{X}_{8}$-індекс споживчих цін на паливо та мастила, \%.

Отже, перший фактор, який пояснює 39,4\% сумарної варіації досліджуваних ознак, інтерпретується як динаміка цін на транспортні послуги.

До значущих показників другого фактору відносяться:

$\mathrm{X}_{3}$ - обсяг експорту товарів, млн дол. США;

$\mathrm{X}_{4}$ - обсяг імпорту товарів, млн дол. США.

Другий фактор, що пояснює 30,3 \% сумарної варіації досліджуваних ознак, пов'язаний із розвитком міжнародної торгівлі України товарами та інтеграцією в міжнародні канали розподілу.

До третього фактору, який пояснює близько $13,4 \%$ сумарної варіації досліджуваних ознак відносяться показники:
$\mathrm{X}_{1}$ - оптовий товарооборот підприємств, млн грн;

$\mathrm{X}_{2}$ - оборот роздрібної торгівлі, млн грн.

Третя компонента пов'язана 3 оптовою та роздрібною внутрішньою торгівлею та характеризує рівень розвитку ринку логістичних послуг в середині країни.

Таким чином запропонована модель дозволяє враховувати вплив на розвиток ринку логістичних послуг трьох груп факторів, які в свою чергу характеризують динаміку змін в зовнішній торгівлі, внутрішній торгівлі та цінах на відповідні послуги чи допоміжні матеріали.

Для перевірки доцільності (якості) використання запропонованої моделі використано формальні способи оцінки іiі якості, а саме Тестом КМО (Кайзера-Мейера-Олкина), який допомагає визначити наскільки модель $є$ адекватною для поставлених цілей, та Тестом Бартлетта - для перевірки доцільність застосування факторного аналізу (табл. 5).

Таблиця 5

Оцінка моделі на основі тестів КМО (Kaiser-Meyer-Olkin) та Bartlett's Test

\begin{tabular}{|c|c|c|}
\hline & Назва тесту & Результат \\
\hline \multicolumn{2}{|c|}{$\begin{array}{l}\text { Kaiser-Meyer-Olkin Measure of Sampling } \\
\text { Adequacy. }\end{array}$} & 0,573 \\
\hline \multirow{3}{*}{$\begin{array}{l}\text { Bartlett's Test of } \\
\text { Sphericity }\end{array}$} & \multirow{3}{*}{$\begin{array}{l}\text { Approx. Chi-Square } \\
\text { qf } \\
\text { Sig. }\end{array}$} & 137,107 \\
\hline & & 21 \\
\hline & & 0,000 \\
\hline
\end{tabular}

Отже, за критерієм КМО (Кайзера - Мейєра Олкіна) наш показник дорівнює 0,573 , що говорить про можливість застосування такої вибірки показників для факторного аналізу, так як він є більшим 0,5.

Застосування ж Bartlett's Test допомагає нам перевірити гіпотезу, про те, що кожна ознака пов'язана сама 3 собою (кореляційна матриця $\epsilon$ діагональною, тобто по діагоналі стоять одиниці, а інші - нулі) і тоді у факторному аналізі немає сенсу. Якщо число Sig суттєво менше за 0,05, то нульова гіпотеза відхиляється, тобто існують зв'язки між різними ознаками, що підтверджує доцільність застосування запропонованого факторного аналізу.

В структурі ринку логістичних послуг України, чітко виділяються два сегменти, а саме: вантажоперевезення i експедирування та складування і інша допоміжна діяльність. Розвиток сегменту вантажоперевезення та експедирування найкраще характеризує такий статистичний показник, як обсяг перевезених вантажів різними видами транспорту, а розвиток сегменту складської логістики характеризує статистичний показник обсягу реалізованих послуг за видом економічної діяльності «Складське господарство та допоміжна діяльність у сфері транспорту».

На наступному етапі дослідження було проведено регресійний аналіз з метою виявлення зв'язків між групою виявлених факторів та показників, які характеризують визначені сегменти розвитку ринку логістичних послуг, а саме:

$\mathrm{Y}_{1}$ - обсяги перевезених вантажів всіма видами транспорту, млн т.; 
$\mathrm{Y}_{2}$ - обсяги перевезених вантажів залізничним транспортом, млн т.;

$\mathrm{Y}_{3}$ - обсяги перевезених вантажів автомобільним транспортом, млн т.;

$\mathrm{Y}_{4}$-обсяги перевезених вантажів водним транспортом, млн т.;

$\mathrm{Y}_{5}$ - обсяги перевезених вантажів трубопровідним транспортом, млн т.;

$\mathrm{Y}_{6}$ - обсяги перевезених вантажів авіаційним транспортом, млн т.;

$\mathrm{Y}_{7}$ - обсяг реалізованих послуг: ВЕД «Складське господарство та допоміжна діяльність у сфері транспорту», млн грн.

Застосування даного статистичного методу дозволяє вирішити такі завдання:

- встановити ступінь залежності визначених показників дослідження ринку від кожного фактору, тобто виміряти тісноту кореляційних зв'язків;
- визначити форму аналітичної залежності показника від фактору;

- розрахувати зміну результативного показника під дією одного або декількох факторів.

По черзі досліджено зв'язок виділених факторів 3 відповідними статистичними показниками, що характеризують розвиток ринку логістичних послуг.

Для перевірки цих передумов за допомогою «Statistica» були розраховані парні коефіцієнти кореляції, як між обгрунтованими факторами, так i між фактором i результативним показником. Матриця парних коефіцієнтів кореляції між факторами та обсягом перевезених вантажів всіма видами транспорту представлена в табл. 6.

Таблиця 6

Матриця парних коефіцієнтів кореляції між факторами та обсягом перевезених вантажів всіма видами транспорту

\begin{tabular}{|c|c|c|c|c|}
\hline № значення & Фактор 1 & Фактор 2 & Фактор 3 & $\mathrm{Y}_{1}$ \\
\hline Фактор 1 & 1,0 & $-0,00$ & 0,00 & $-0,08$ \\
\hline Фактор 2 & $-0,00$ & 1,0 & 0,00 & $\mathbf{0 , 7 8}$ \\
\hline Фактор 3 & 0,00 & 0,00 & 1,0 & $-0,08$ \\
\hline $\mathrm{Y}_{1}$ & $-0,08$ & $\mathbf{0 , 7 8}$ & $-0,08$ & 1,0 \\
\hline
\end{tabular}

3 таблиці 6 видно, що статистично значущою в даному випадку є одна кореляція: Фактор 2 має прямий $(0,78>0)$ досить тісний зв'язок (більше за 0,75) зі змінною $\mathrm{Y}_{1}$. Тобто найбільш тісний взаємозв'язок існує між обсягами перевезених вантажів всіма видами транспорту та показниками розвитку зовнішньої торгівлі, а саме обсягами експорту та імпорту товарів безпосередньо призводить збільшення обсягів вантажних перевезень.

Матриця парних коефіцієнтів кореляції між визначеними групами факторів та обсягом перевезених вантажів залізничним транспортом ( $\left.\mathrm{Y}_{2}\right)$ представлена в табл. 7.

експорту та імпорту товарів. Збільшення обсягів

Таблиця 7

Матриця парних коефіцієнтів кореляції між факторами та обсягом перевезених вантажів залізничним

\begin{tabular}{|c|c|c|c|c|}
\hline \multicolumn{5}{|c|}{ транспортом } \\
\hline № значення & Фактор 1 & Фактор 2 & Фактор 3 & $\mathrm{Y}_{2}$ \\
\hline Фактор 1 & 1,0 & $-0,00$ & 0,00 & 0,03 \\
\hline Фактор 2 & $-0,00$ & 1,0 & 0,00 & $\mathbf{0 , 5 4}$ \\
\hline Фактор 3 & 0,00 & 0,00 & 1,0 & $\mathbf{- 0 , 4 9}$ \\
\hline$Y_{2}$ & 0,03 & $\mathbf{0 , 5 4}$ & $\mathbf{- 0 , 4 9}$ & 1,0 \\
\hline
\end{tabular}

3 таблиці 7 видно, що статистично значимими в даному випадку $є$ дві кореляції: Фактор 2 має прямий $(0,54>0)$ зв'язок, однак ступінь сили середній (більше за 0,5 ) зі змінною $\mathrm{Y}_{2}$. Тобто прослідковується прямий взаємозв'язок між обсягами перевезених вантажів залізничним транспортом та показниками розвитку зовнішньої торгівлі, а саме обсягами експорту та імпорту товарів. Збільшення обсягів експорту та імпорту товарів призводить до збільшення обсягів вантажних перевезень залізничним транспортом. При цьому існує обернений зв'язок, між обсягами перевезених вантажів залізничним транспортом та групою факторів, що характеризує розвиток внутрішньої торгівлі. Збільшення обсягів оптового та роздрібного товарообороту може призвести до зменшення обсягів перевезень вантажів залізничним транспортом. Такий зв'язок слабкий, але він існує і 
може пояснюватися економічною необгрунтованістю використання залізничного транспорту для перевезення вантажів на короткі відстані.

Матриця парних коефіцієнтів кореляції між визначеними групами факторів та обсягом перевезених вантажів автомобільним транспортом $\left(\mathrm{Y}_{3}\right)$ представлена в табл. 8.

Таблиця 8

Матриця парних коефіцієнтів кореляції між факторами та обсягом перевезених вантажів автомобільним транспортом

\begin{tabular}{|c|c|c|c|c|}
\hline № значення & Фактор 1 & Фактор 2 & Фактор 3 & $\mathrm{Y}_{3}$ \\
\hline Фактор 1 & 1,0 & $-0,00$ & 0,00 & $-0,08$ \\
\hline Фактор 2 & $-0,00$ & 1,0 & 0,00 & $\mathbf{0 , 5 5}$ \\
\hline Фактор 3 & 0,00 & 0,00 & 1,0 & $\mathbf{0 , 6 3}$ \\
\hline $\mathrm{Y}_{3}$ & $-0,08$ & $\mathbf{0 , 5 5}$ & $\mathbf{0 , 6 3}$ & 1,0 \\
\hline
\end{tabular}

3 таблиці 8 видно, що статистично значимими в даному випадку є дві кореляції: Фактори 2 та 3 мають прямий зв'язок $(0,54>0$ та $0,63>0)$ зі змінною

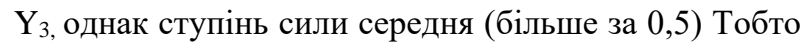
прослідковується прямий взаємозв'язок між обсягами перевезених вантажів автомобільним транспортом та показниками розвитку зовнішньої торгівлі, а саме обсягами експорту та імпорту товарів. При цьому зміни в обсягів оптового та роздрібного товарообороту будуть сильніше впливати на зміни обсягів вантажних перевезень автомобільним транспортом, а ніж обсяги експорту та імпорту товарів.

Варто відзначити, що проведені дослідження впливу виокремлених груп факторів на обсяги перевезених вантажів водним транспортом ( $\left.\mathrm{Y}_{4}\right)$ та авіаційним транспортом $\left(\mathrm{Y}_{6}\right)$ не дозволило визначити жодного фактору, який би здійснював на них хоча б якийсь вплив. Це пояснюється тим, що частка перевезень вантажів водним транспортом не перевищує 0,4 \% загального обсягу всіх вантажних перевезень, а частка перевезень вантажів авіаційним транспортом взагалі складає $0,01 \%$ загального обсягу всіх вантажних перевезень. Обсяги перевезених вантажів даними видами транспорту настільки не значні, відносно обсягу перевезених вантажів всіма видами транспорту, що і зміни обсягів внутрішньої та зовнішньої торгівлі, а також зміни цін на них суттєво не відображаються.

Матриця парних коефіцієнтів кореляції між визначеними групами факторів та обсягом перевезених вантажів трубопровідним транспортом ( $\left.\mathrm{Y}_{5}\right)$ представлена в табл. 9.

Таблиця 9

Матриця парних коефіцієнтів кореляції між факторами та обсягом перевезених вантажів трубопровідним транспортом

\begin{tabular}{|c|c|c|c|c|}
\hline № значення & Фактор 1 & Фактор 2 & Фактор 3 & $\mathrm{Y}_{5}$ \\
\hline Фактор 1 & 1,0 & $-0,00$ & 0,00 & $-0,10$ \\
\hline Фактор 2 & $-0,00$ & 1,0 & 0,00 & $\mathbf{0 , 4 1}$ \\
\hline Фактор 3 & 0,00 & 0,00 & 1,0 & $-0,13$ \\
\hline $\mathrm{Y}_{5}$ & $-0,10$ & $\mathbf{0 , 4 1}$ & $-0,13$ & 1,0 \\
\hline
\end{tabular}

3 таблиці 9 видно, що статистично значимими в даному випадку є одна кореляція: Фактор 2 має прямий зв'язок $(0,41>0)$ зі змінною $\mathrm{Y}_{5}$, однак ступінь сили низький (менше за 0,5 ) Тобто прослідковується прямий взаємозв'язок між обсягами перевезених вантажів трубопровідним транспортом та показниками розвитку зовнішньої торгівлі, а саме обсягами експорту та імпорту товарів, а саме нафти, газу, нафтопродуктів та ін.

Матриця парних коефіцієнтів кореляції між визначеними групами факторів та обсягом реалізованих послуг виду економічної діяльності «Складське господарство та допоміжна діяльність у сфері транспорту» $\left(\mathrm{Y}_{7}\right)$ представлена в табл. 10.
3 таблиці 10 видно, що статистично значимим в даному випадку є одна кореляція: Фактор 3 має прямий зв'язок $(0,84>0)$ зі змінною $\mathrm{Y}_{7}$, ступінь сили високий (більший за 0,7 ) Тобто прослідковується прямий взаємозв'язок між фактором, що характеризує розвиток внутрішньої торгівлі, а саме обсягами оптового та роздрібного товарообороту та розвитком складської логістики, яке характеризується обсягом реалізованих послуг виду економічної діяльності «Складське господарство та допоміжна діяльність у сфері транспорту». Збільшення обсягів оптового та роздрібного товарообороту призведе до підвищення попиту на складські послуги та розвиток допоміжної діяльності у сфері транспорту. 
Таблиця 10

Матриця парних коефіцієнтів кореляції між факторами та обсягом реалізованих послуг виду економічної діяльності «Складське господарство та допоміжна діяльність у сфері транспорту»

\begin{tabular}{|c|c|c|c|c|}
\hline № значення & Фактор 1 & Фактор 2 & Фактор 3 & $\mathrm{Y}_{7}$ \\
\hline Фактор 1 & 1,0 & $-0,00$ & 0,00 & $-0,24$ \\
\hline Фактор 2 & $-0,00$ & 1,0 & 0,00 & $-0,03$ \\
\hline Фактор 3 & 0,00 & 0,00 & 1,0 & $\mathbf{0 , 8 4}$ \\
\hline $\mathrm{Y}_{7}$ & $-0,24$ & $-0,03$ & $\mathbf{0 , 8 4}$ & 1,0 \\
\hline
\end{tabular}

Наступним етапом було побудова регресійного рівняння за встановленими кореляційними зв'язками на основі використання пакету SPSS, визначені коефіцієнти регресії допомогли виписати рівняння:

$$
\mathrm{Y}_{1}=109,24+0,004 * \mathrm{X}_{4}
$$

де, обсяг імпорту товарів, млн дол. США, який входить до фактору 2.

Дане рівняння описує зміну $\mathrm{Y}_{1}$ у $(0,647 * 100=64,7$ приблизно 65\%) 65\% випадків.

Розрахунки показують, що при збільшенні обсягу імпорту товарів на 1 млрд дол. США обсяг перевезення вантажів всіма видами транспорту збільшиться на 3,97 млн т. Якщо імпорт-експорт товарів взагалі припиниться, то обсяг перевезення вантажів всіма видами транспорту в середньому буде становити 109,24 млн т.

\section{Висновки}

На основі побудованої моделі головних компонент виявлено ключові фактори розвитку ринку логістичних послуг в Україні. В ході реалізації методу виділено три фактори, що пояснюють 83,1 \% сумарної варіації досліджуваних ознак, а саме: динаміка цін на транспортні послуги (вплив - 39,4\%); обсяг міжнародної торгівлі України товарами (вплив - 30,3\%); оптовий та роздрібний внутрішній товарооборот України (вплив - 13,4\%).

Проведене дослідження 3 використанням методу головних компонент показало можливість об'єктивного виділення факторів розвитку ринку логістичних послуг.

Виділені фактори дозволяють здійснити наукове обгрунтування основних напрямів державного регулювання ринку логістичних послуг та розробити пропозиції щодо вдосконалення (підвищення ефективності) роботи логістичних підприємств в Україні на основі побудованих регресійних моделей.

Виявлення факторів за запропонованою методикою дозволяє з'ясувати їх вплив, але не повною мірою дає можливість встановити сам механізм впливу, тому напрямом подальших досліджень повинно стати виявлення прихованих змінних, які визначають наявність статистичних кореляцій.

\section{Лiтература}

1. Григорак М. Ю. Інтелектуалізація ринку логістичних послуг: концепція, методологія, компетентність: монографія. К.: Сік Груп Украӥна, 2017. с. 513

2. Yingjie Ju, Yue Wang, Ye Cheng and Jun Jia. Investigating the Impact Factors of the Logistics Service Supply Chain for Sustainable Performance: Focused on Integrators Sustainability 2019, 11, 538.

3. Lazzat Gabdullina, Kasiya Kirdasinovaa, Assemgul Amanbayevab, Aigul Zeinullinac, Elvira Tlessovaa and Saule A. Azylkanovaa. Transport and logistics innovations in supply chain management: Evidence from Kazakhstan. Uncertain Supply Chain Management. 2020, 8, 255-266.

4. Пойта I. О., Горик-Чубатюк М. О. Основні виклики та перспективи розвитку транспортної логістики в Україні. Вісник [Київського інституту бізнесу та технологій]. 2019. Buпуск №2 (40). C. 35-39

5. Supachart Iamratanakul. Modeling the macroenvironmental factors of international distribution URL.: http://www.toknowpress.net/ISBN/978-961-6914-13-

0/papers/ML15-125.pdf (date of application 26.09.20)

6. Pham Van Honga, Thanh-Thuy Nguyen. Factors affecting marketing strategy of logistics business - Case of Vietnam The Asian. Journal of Shipping and Logistics, 3 August 2020 URL.:https://www.sciencedirect.com/science/article/pii/S2092 521220300213 (date of application 26.09.20)

7. Chieh-Yu Lin. Influences of Individual, Organizational and Environmenta lFactors on Technological Innovation in Taiwan's Logistics Industry URL.: http://www.jgbm.org/page/8\%20Dr.\%20Chieh-Yu\%20Lin.pdf (date of application 22.09.20)

8. Шандрівська О. Є., Якимишин Л. Я. Дослідження глобального ринку логістичних послуг: світові тенденціі та вплив на Україну. Вісник Національного університету "Львівська політехніка". Логістика. 2018. № 892. С. 212221.

9. Сріна А. М., Срін Д.Л. Статистичне моделювання та прогнозування: підруч. К.: КНЕУ 2014, с. 348.

10. Офічійний сайт Державної служби статистики України URL: http://www.ukrstat.gov.ua/

\section{References}

1. Hryhorak M. YU. Intelektualizatsiya rynku lohistychnykh posluh: kontseptsiya, metodolohiya, kompetentnist': monohrafiya. K.: Sik Hrup Ukrayina, 2017. s. 513. 
2. Yingjie Ju, Yue Wang, Ye Cheng and Jun Jia. Investigating the Impact Factors of the Logistics Service Supply Chain for Sustainable Performance: Focused on Integrators Sustainability 2019, 11, 538 .

3. Lazzat Gabdullina, Kasiya Kirdasinovaa, Assemgul Amanbayevab, Aigul Zeinullinac, Elvira Tlessovaa and Saule A. Azylkanovaa. Transport and logistics innovations in supply chain management: Evidence from Kazakhstan. Uncertain Supply Chain Management. 2020, 8, 255-266.

4. Poyta I. O., Horyk-Chubatyuk M. O. Osnovni vyklyky ta perspektyvy rozvytku transportnoyi lohistyky v Ukrayini. Visnyk [Kyyivs'koho instytutu biznesu ta tekhnolohiy]. 2019. Vypusk №2 (40). S. 35-39

5. Supachart Iamratanakul. Modeling the macroenvironmental factors of international distribution URL.: http://www.toknowpress.net/ISBN/978-961-6914-13-

0/papers/ML15-125.pdf (date of application 26.09.20)

6. Pham Van Honga, Thanh-Thuy Nguyen. Factors affecting marketing strategy of logistics business - Case of Vietnam The Asian. Journal of Shipping and Logistics, 3 August 2020 URL.:https://www.sciencedirect.com/science/article/pii/S2092 521220300213 (date of application 26.09.20)

7. Chieh-Yu Lin. Influences of Individual, Organizational and Environmenta 1Factors on Technological Innovation in Taiwan's Logistics Industry URL.:
http://www.jgbm.org/page/8\%20Dr.\%20Chieh-Yu\%20Lin.pdf (date of application 22.09.20)

8. Shandrivs'ka O. YE., Yakymyshyn L. YA. Doslidzhennya hlobal'noho rynku lohistychnykh posluh: svitovi tendentsiyi ta vplyv na Ukrayinu. Visnyk Natsional'noho universytetu "L'vivs'ka politekhnika". Lohistyka. 2018. № 892. S. 212-221. 9. Yerina A. M., Yerin D. L. Statystychne modelyuvannya ta prohnozuvannya: pidruch. K.: KNEU 2014, s. 348.

10. Ofitsiynyy sayt Derzhavnoyi sluzhby statystyky Ukrayiny URL: http://www.ukrstat.gov.ua/

Рецензент: д.е.н., професор, проректор 3 науковопедагогічної та виховної роботи Л.Є. Момотюк, Національної академії статистики, обліку та аудиту, Україна

Автор: ГРИНЧАК Наталія Анатоліївна старший викладач кафедри економіки та менеджменту зовнішньоекономічної діяльності, Національна академія статистики, обліку та aydumy

E-mail-gnatalia@ukr.net

ID ORCID: http://orcid.org/0000-0002-2046-6014

\section{APPLICATION OF THE MAIN COMPONENTS METHOD FOR DETERMINATION OF FACTORS OF LOGISTICS SERVICES MARKET DEVELOPMENT OF UKRAINE}

N.A. Hrynchak

National Academy of Statistics, Accounting and Audit, Ukraine

The study identifies and substantiates the main factors influencing the development of the market of logistics services in Ukraine through factor analysis by the method of main components. The application of the method of factor analysis to assess the development of the market of logistics services is based on the assumption that the indicators of different blocks are only indicators of certain existing market characteristics that are not directly measured. 9 indicators were selected for the study: wholesale turnover of enterprises, retail trade turnover, volume of exports of goods, volume of imports of goods, hryvnia devaluation index against the US dollar, rail freight index, consumer price index for transport, consumer price index for fuel and lubricants, consumer price index for transport services.

Bartlett's sphericity criterion and the calculation of the adequacy of the Kaiser-Mayer-Olkin sample were used for the study. It was found that the largest variance has such components as price indices for transport, fuels and lubricants, the volume of foreign and domestic (wholesale and retail) trade, which total 83.1\%. The analysis of factors according to the received calculations is made.A study of factor analysis of the development of the market of logistics services showed that the segment of freight and warehousing logistics is not significantly affected by indicators combined in the component that characterized the price indices for transport, transport services, etc., is changes in domestic and foreign trade are greater impact on changes in the volume of these segments, regardless of changes in prices for services and related goods in the market of logistics services.

The selection of factors according to the proposed method allows to determine their influence, but does not fully clarify the mechanism of influence, so the direction of further research should be to identify hidden variables that determine the presence of statistical correlations.

Keywords: freight transportation, Principal components, market of logistic services, warehousing, statistical estimation, factor analysis. 